\title{
Blastococcus saxobsidens sp. nov., and emended descriptions of the genus Blastococcus Ahrens and Moll 1970 and Blastococcus aggregatus Ahrens and Moll 1970
}

\author{
Clara Urzì, ${ }^{1}$ Paola Salamone, ${ }^{1}$ Peter Schumann, ${ }^{2}$ Manfred Rohde ${ }^{3}$ \\ and Erko Stackebrandt ${ }^{2}$
}

Correspondence

Erko Stackebrandt erko@dsmz.de

\author{
${ }^{1}$ Department of Microbiological, Genetic and Molecular Sciences, University of Messina, Salita \\ Sperone 31, I-98166 Messina, Italy \\ ${ }^{2} \mathrm{DSMZ}$ - German Collection of Microorganisms and Cell Cultures $\mathrm{GmbH}$, Mascheroder \\ Weg 1b, D-38124 Braunschweig, Germany \\ ${ }^{3} \mathrm{GBF}$ - Gesellschaft für Biotechnologische Forschung mbH, Mascheroder Weg 1b, D-38124 \\ Braunschweig, Germany
}

\begin{abstract}
Ten Gram-positive, aerobic bacterial strains with coccoid cells occurring singly, in pairs, tetrads and small aggregates were isolated from the surface of marble and calcareous stones. The peptidoglycan contained meso-diaminopimelic acid as the diagnostic diamino acid. The major menaquinone was MK-9 $\left(\mathrm{H}_{4}\right)$. The cellular fatty acid pattern consisted mainly of iso-branched chain components. According to their phylogenetic position, the organisms are members of the family Geodermatophilaceae, clustering close to Blastococcus aggregatus DSM $4725^{\top}$. Based on a combination of phenotypic, chemotaxonomic and genotypic characteristics, strain $\mathrm{BC} 444^{\top}$ and seven relatives group apart from strains BC412 (=DSM 44517) and BC521 (=DSM 44518), which themselves form two individual lineages. DNA-DNA reassociation studies revealed that members of the three lineages were only remotely related to $B$. aggregatus DSM $4725^{\top}$; as the strain-rich cluster containing $B C 444^{\top}$ shared low DNA similarity values with strains BC412 and BC521, it will be described as a novel species of Blastococcus, for which the name Blastococcus saxobsidens sp. nov. is proposed. The type strain is BC $444^{\top}$ $\left(=\mathrm{DSM} 44509^{\top}=\right.$ NRRL $\left.24246^{\top}\right)$.
\end{abstract}

Isolates resembling members of the family Geodermatophilaceae from altered stone surfaces from monuments and natural stones in the Mediterranean basin have recently been demonstrated to belong phylogenetically to the genera Geodermatophilus (Eppard et al., 1996), Modestobacter (Mevs et al., 2000) and Blastococcus (Ahrens \& Moll, 1970; Urzì et al., 2001). The result of a detailed taxonomic investigation of some of the isolates that cluster with Blastococcus aggregans is reported.

Published online ahead of print on 29 August 2003 as DOI 10.1099/ ijs.0.02745-0.

Abbreviation: $A_{2} p m$, diaminopimelic acid.

The GenBank/EMBL/DDBJ accession numbers for the 16S rRNA gene sequences of strains $\mathrm{BC512}, \mathrm{BC} 444^{\top}, \mathrm{BC5} 17, \mathrm{BC5} 21$ and BC412 are AJ316570-AJ316574.

Detailed fatty acid compositions of $B$. aggregatus DSM $4725^{\top}$ and nine novel strains are available as supplementary material in IJSEM Online.

\section{Isolation and cultivation}

Ten strains were isolated from various sites (Table 1) by dilution plating on Bunt \& Rovira medium (Bunt \& Rovira, 1955), modified by addition of $0 \cdot 5 \%$ glucose, $0.5 \% \mathrm{NaCl}$ and $0.03 \% \mathrm{Na}_{2} \mathrm{CO}_{3}, \mathrm{pH} 8.6$ (medium BRII), and maintained in Luedemann medium (LM; Luedemann, 1968). Growth was tested on LM agar plates at 6, 10, 20, 32, 37 and $45^{\circ} \mathrm{C}$. $\mathrm{NaCl}$ tolerance was checked at concentrations of $0 \cdot 5,3,5,6$ and $10 \%(\mathrm{w} / \mathrm{v})$. Growth at different $\mathrm{pH}$ values was tested at $\mathrm{pH} 4,5,6 \cdot 8,8 \cdot 6,10$ and 12 .

Sparse growth occurred after 2 weeks at $28^{\circ} \mathrm{C}$ on LM, malt extract agar (Oxoid) (no growth for strain BC519) and on YCS-Glc agar $[0.5 \%$ yeast extract (YE), $1.5 \%$ casein hydrolysates, $1 \%$ starch, $1 \%$ glucose, $1.5 \%$ agar] and YG-Glyc agar ( $0.5 \%$ YE, $1 \%$ glucose, $10 \%$ glycerol, $1.5 \%$ agar; Luedemann \& Fonseca, 1989) (no growth for strain BC521). Growth was not supported on potato dextrose agar (Oxoid). Growth was observed at 20 and $37^{\circ} \mathrm{C}$, with an optimum at $32^{\circ} \mathrm{C}$. Strains BC412 and BC518 also grew at 
Table 1. Isolation sites of $B C$ strains

\begin{tabular}{|lll|}
\hline Strain(s) & Origin & \multicolumn{1}{c|}{ Site } \\
\hline BC412, BC448 & Marble & Archaeological site, Eleusys, Greece \\
BC444 $^{\mathrm{T}}$ & Limestone & Church, Siggiewi, Malta \\
BC509, BC512, BC517, BC518, & Calcarenite & 'Santa Maria La Scala' quarry, Noto, Italy \\
BC519, BC521, BC525 & & \\
\hline
\end{tabular}

$15^{\circ} \mathrm{C}$. No growth occurred below $10{ }^{\circ} \mathrm{C}$ or at $45^{\circ} \mathrm{C}$. Growth in $\mathrm{LM}$ occurred at $\mathrm{pH} 5-8.6$ with an optimum at $\mathrm{pH} 6 \cdot 8$; except for strains BC412, BC512 and BC521, which grew at up to $\mathrm{pH} 8 \cdot 6$, all strains grew at up to $\mathrm{pH} 10 \cdot 5$. No growth was observed at or above $3 \% \mathrm{NaCl}$, except for strain BC448, which grew at $5 \% \mathrm{NaCl}$.

\section{Colony and cell morphology}

Cell and aggregate morphology were determined by brightfield microscopy and by phase-contrast microscopy (DML; Leica) (oil-immersion objective, magnification $\times 100$ ). For scanning electron microscopy analysis, bacterial samples were dehydrated with a graded series of acetone, criticalpoint-dried with $\mathrm{CO}_{2}$ and sputter-coated with gold before examination in a Zeiss field emission scanning electron microscope DSM982 Gemini at $5 \mathrm{kV}$ using the EverhartThornley SE-detector and the in-lens SE-detector in a 50:50 ratio. Morphology of colonies was studied with a stereomicroscope (Wild M10; Leica). Colonies of all strains were pink- to orange-pigmented, circular (diameter 2-3 mm) with a smooth or rough surface. Cell morphology was characterized by coccoid cells $(0 \cdot 5-1 \cdot 7 \mu \mathrm{m}$ in diameter) occurring singly, in pairs or in tetrads, often tending to form aggregates (Fig. 1a, b). Under the conditions used, bud formation was observed only for strains BC412, BC509, BC517, BC518 and BC521, and small motile zoospores were produced by BC509, BC412 and BC521. Strains BC412 and BC521 formed elongated cells, produce germ tubes and long filaments.

\section{Chemotaxonomy}

The fatty acid profiles (Stead et al., 1992; Schumann et al., 1997) of B. aggregatus DSM $4725^{\mathrm{T}}$ and the BC strains were characterized by the predominance of iso- $\mathrm{C}_{16: 0}$ and iso$\mathrm{C}_{16: 1}$ acids. Other fatty acids, some occurring in major amounts $\left(\mathrm{C}_{17: 1} \omega 8 c\right)$, differed among strains and are indicated in the species description. The fatty acid profiles are available as supplementary material in IJSEM Online. The major respiratory quinones, determined as described previously (Collins et al., 1977; Groth et al., 1996), were MK$9\left(\mathrm{H}_{4}\right)$ and MK-9; homologues of the $\mathrm{H}_{4}$ series $(7,8)$ as well as the MK-9 series $\left(\mathrm{H}_{2}, \mathrm{H}_{6}\right)$ may occur in minor amounts. The polar lipid pattern (Minnikin et al., 1979; Collins \& Jones, 1980) of strain BC444 ${ }^{\mathrm{T}}$ consisted of diphosphatidylglycerol, phosphatidylglycerol, phosphatidylinositol and phosphatidylethanolamine. B. aggregatus DSM $4725^{\mathrm{T}}$ and strain BC412 also contained two unknown phospholipids. The cell walls of strains $\mathrm{BC} 444^{\mathrm{T}}, \mathrm{BC} 521$ and BC412 and of B. aggregatus DSM $4725^{\mathrm{T}}$ contained mesodiaminopimelic acid (meso- $\left.\mathrm{A}_{2} \mathrm{pm}\right)$, confirming the observation stated to be characteristic of members of the family Geodermatophilaceae (Normand et al., 1996). The DNA $\mathrm{G}+\mathrm{C}$ content (Mesbah et al., 1989) of B. aggregatus DSM $4725^{\mathrm{T}}$ was $73 \cdot 9 \mathrm{~mol} \%$.

\section{Phylogenetic analyses}

Of the isolates for which partial 16S rRNA gene sequences (5550 nucleotides) have been published previously (Urzì et al., 2001), six strains were selected for determination of almost complete sequences. These strains represented
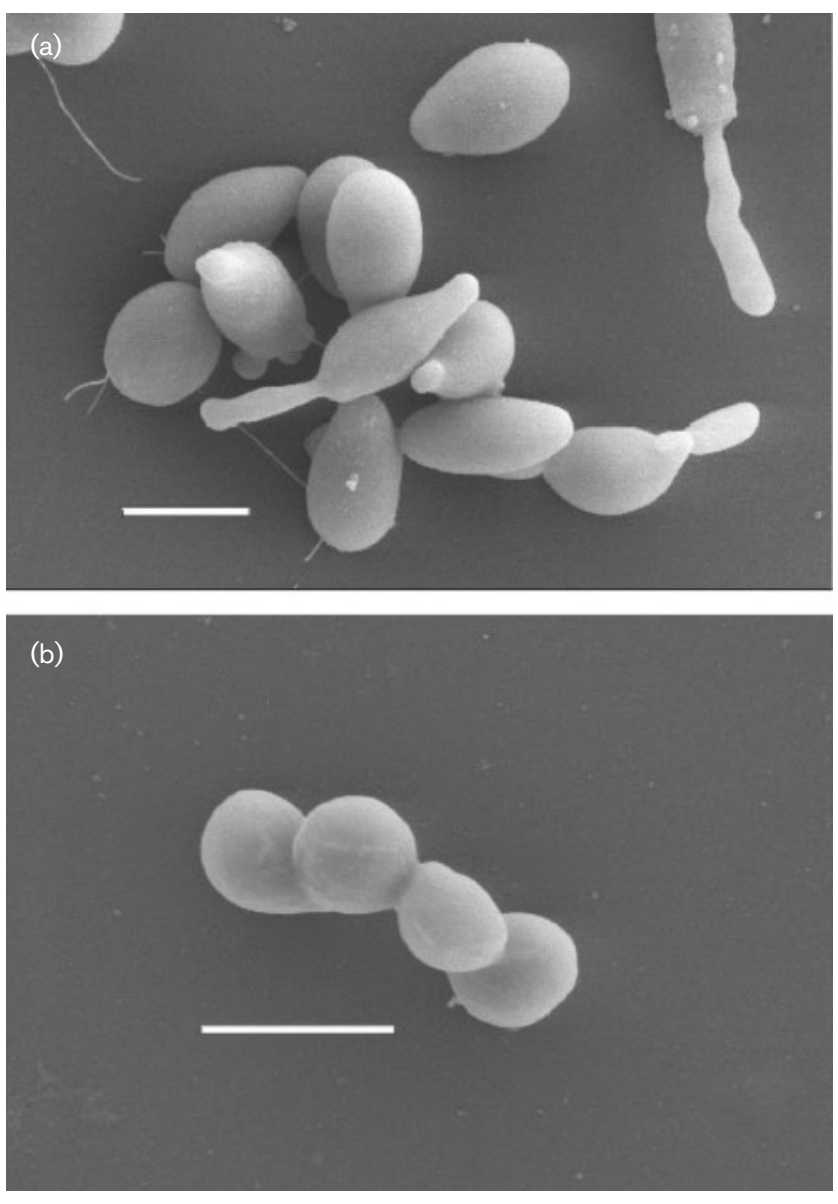

Fig. 1. Electron micrographs of $B$. aggregatus DSM $4725^{\top}$ (a) and strain $B C 444^{\top}$ (b). Bars, $1 \mu \mathrm{m}$. 


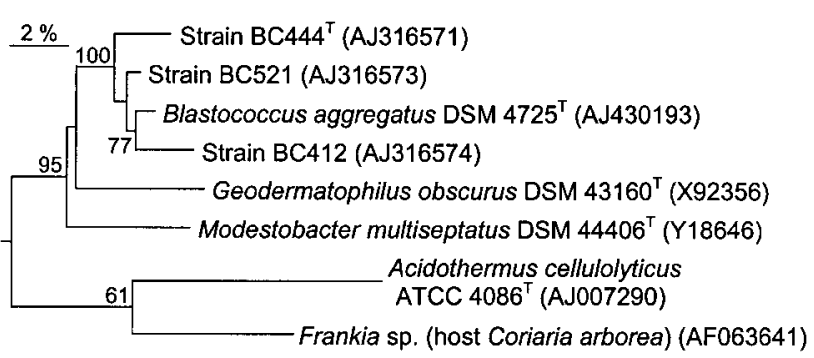

Fig. 2. $16 \mathrm{~S}$ rRNA gene sequence-based dendrogram, displaying the relatedness of Blastococcus-like organisms to type strains of species of Geodermatophilus, Modestobacter and Blastococcus (Eppard et al., 1996). The sequences of members of Micrococcineae served as an outside reference. Bootstrap percentages (1000 replicates, $>70 \%$ confidence) are indicated at respective nodes. Bar, $2 \%$ sequence difference.

three different lineages, branching adjacent to that of B. aggregatus DSM $4725^{\mathrm{T}}$. Sequencing methods and analyses of phylogenetic relatedness followed described procedures (Rainey et al., 1996). The phylogenetic analysis supported analyses based on partial sequences: three lineages emerged, defined by strains $\mathrm{BC} 444^{\mathrm{T}} / \mathrm{BC} 448 /$ BC512/BC517, sharing $>99.9 \%$ similarity, BC412 and BC521; sequences of members of these lineages were $97 \cdot 6$ $98 \cdot 2 \%$ similar among themselves. B. aggregatus DSM $4725^{\mathrm{T}}$ was about equidistantly related to the BC521 and BC412 lineages (99.2 and $98.6 \%$ similar) and slightly less closely related to strain $\mathrm{BC} 444^{\mathrm{T}}$ and related strains $(98 \cdot 0 \%)$. Based upon partial sequences, the $\mathrm{BC} 444^{\mathrm{T}}$ lineage contained several additional isolates that were $>99.9 \%$ similar to strain $\mathrm{BC} 444^{\mathrm{T}}$ (Urzì et al., 2001). Similarity values were transformed into phylogenetic distance values that compensate for multiple substitutions at any given site in the sequence (Jukes \& Cantor, 1969). A distance matrix dendrogram (DeSoete, 1983) is shown in Fig. 2.

The genomic homogeneity of some members of the BC $444^{\mathrm{T}}$ lineage was determined in comparison to some other $\mathrm{BC}$ isolates and B. aggregatus DSM $4725^{\mathrm{T}}$ by RiboPrint analysis (Bruce, 1996; Stackebrandt et al., 2002) using the restriction enzymes PvuII and PstI. The patterns were in accord with $16 \mathrm{~S}$ rRNA gene sequence analysis in that members of the
BC $444^{\mathrm{T}}$ cluster were homogeneous, while members of the other lineages were defined by individual patterns (Fig. 3).

Discrimination at a lower taxonomic level by DNA-DNA hybridization (Escara \& Hutton, 1980; Huß et al., 1983; Jahnke, 1992) revealed that strain $\mathrm{BC} 444^{\mathrm{T}}$ shared only $39 \%$ similarity with strain $\mathrm{BC} 412$ and $50 \%$ similarity with strain BC521. All three isolates were clearly unrelated to $B$. aggregatus DSM $4725^{\mathrm{T}}$ (25-37\% similarity). Because of the low sequence similarity $(98 \cdot 2 \%)$, the binary DNADNA reassociation value was not determined for strains BC521 and BC412.

\section{Physiology}

Physiological tests were performed at $28^{\circ} \mathrm{C}$ using Biolog GN, API ZYM and API 20 NE substrate panels. Catalase and oxidase activities were determined by the formation of bubbles in a $3 \%$ hydrogen peroxide solution; oxidation of $N, N, N^{\prime}, N^{\prime}$-tetramethyl-p-phenylenediamine was done on filter paper. Properties are compiled in Table 2. The metabolic reactions of members of the three novel Blastococcus lineages showed significant differences from that of $B$. aggregatus DSM $4725^{\mathrm{T}}$ as well as among themselves.

\section{Taxonomic conclusions}

Urzì et al. (2001) studied 65 isolates from natural stones and monuments attributed to the family Geodermatophilaceae and showed that, on rock surfaces, members of the genera Geodermatophilus, Modestobacter and Blastococcus had different distributions. In fact, strains belonging phylogenetically to Geodermatophilus were very rare, while strains belonging to Modestobacter were very common and were distributed on stone surfaces located in different climates. Strains taxonomically affiliated to the only species of the genus Blastococcus, B. aggregatus, isolated from the Baltic Sea (Ahrens \& Moll, 1970), were found on rock surfaces located in the Mediterranean basin and, in particular, they were isolated from monuments and rocks in Greece, Italy and Malta. The ten strains share a few characteristics with $B$. aggregatus (Table 2) such as the formation of pink/orange colonies, aerobic metabolism and the presence of $\mathrm{MK}-9\left(\mathrm{H}_{4}\right)$ as the predominant menaquinone. On the other hand, differences were observed in (a)

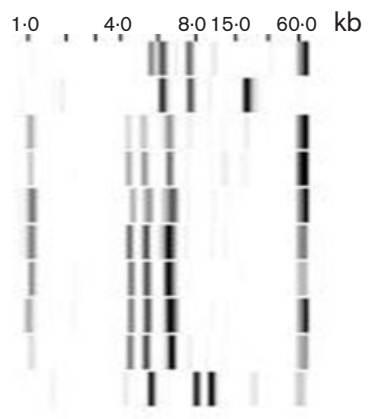

(b)

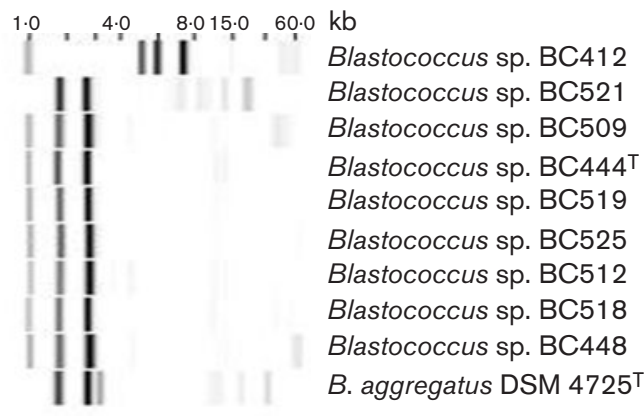

Fig. 3. RiboPrint patterns of $B$. aggregatus DSM $4725^{\top}$ and novel Blastococcus isolates, generated with Pvull (a) and Pstl (b). 
Table 2. Differentiation between strains DSM $4725^{\top}$ and other isolates using morphological and physiological parameters

Tests are scored as:,$+>80 \%$ positive,,$-<10 \%$ positive, $\mathrm{V}, 10-80 \%$ positive; $\mathrm{V}^{\mathrm{w}}$, variable (mostly weak); $\mathrm{W}$, weak reaction. Reaction of type strain $\mathrm{BC} 444^{\mathrm{T}}$ is given in parentheses. All strains formed aggregates and were positive or weak for the following reactions: esterase (C4), esterase (C8), leucine arylamidase, Tweens 40 and 80 , D-ribose and methyl succinate. All strains were negative for nitrate reduction, indole, glucose fermentation, urease, $\beta$-glucosidase, assimilation of mannitol, $N$-acetylglucosamine, maltose, caproate, citrate and phenylacetate, lipase, $\alpha$-galactosidase, $\beta$-galactosidase, $N$-acetyl- $\beta$-glucosaminidase, $\alpha$-mannosidase, $\alpha$-fucosidase and trypsin (API 20NE and API ZYM). Reactions towards the other 67 substrates provided by the Biolog GP2 panel were negative.

\begin{tabular}{|c|c|c|c|c|}
\hline Test & $\begin{array}{l}\text { B. aggregatus } \\
\text { DSM } 4725^{\mathrm{T}}\end{array}$ & $\begin{array}{c}\mathrm{BC} 444^{\mathrm{T}} \text { and seven } \\
\text { related strains }\end{array}$ & BC521 & BC412 \\
\hline Cell shape ${ }^{\star}$ & $C, R$, vibrios & $\mathrm{C}$ & $\mathrm{C} / \mathrm{R}$ & $\mathrm{C} / \mathrm{R}$ \\
\hline Bud formation & + & - (except one strain) & + & + \\
\hline Germ tube & + & - & + & + \\
\hline Motility & + & $\mathrm{V}$ & + & + \\
\hline Oxygen requirement & Aerobic/microaerophilic & Aerobic & Aerobic & Aerobic \\
\hline Colony colour $\dagger$ & $\mathrm{P}$ & $\mathrm{P} / \mathrm{O}$ & $\mathrm{P} / \mathrm{O}$ & $\mathrm{P}$ \\
\hline \multicolumn{5}{|l|}{ API $20 \mathrm{NE}$} \\
\hline Arginine dihydrolase & - & $\mathrm{v}(+)$ & - & - \\
\hline$\beta$-Galactosidase & - & + & + & + \\
\hline \multicolumn{5}{|l|}{ Assimilation of: } \\
\hline Glucose & - & - & $\mathrm{W}$ & $\mathrm{W}$ \\
\hline Arabinose & - & + & + & + \\
\hline Adipate & - & $\mathrm{w}(-)$ & + & $\mathrm{W}$ \\
\hline Mannose & - & $\mathrm{V}^{\mathrm{W}}(-)$ & - & - \\
\hline Gluconate & - & $\mathrm{w}$ & - & - \\
\hline Malate & - & $\mathrm{V}$ & - & - \\
\hline \multicolumn{5}{|l|}{ API ZYM } \\
\hline Valine arylamidase & - & $\mathrm{V}(-)$ & $\mathrm{W}$ & + \\
\hline Alkaline phosphatase & - & + & - & $\mathrm{W}$ \\
\hline Cystine arylamidase & - & $\mathrm{V}^{\mathrm{W}}(-)$ & $\mathrm{W}$ & - \\
\hline Naphthol-AS-BI-phosphohydrolase & - & $\mathrm{V}^{\mathrm{W}}$ & - & $\mathrm{W}$ \\
\hline$\alpha$-Glucosidase & $\mathrm{W}$ & + & - & + \\
\hline$\beta$-Glucosidase & - & $\mathrm{W}$ & - & W \\
\hline$\beta$-Glucuronidase & - & $\mathrm{V}(+)$ & - & - \\
\hline \multicolumn{5}{|l|}{ Biolog GP2 } \\
\hline \multicolumn{5}{|l|}{ Utilization of: } \\
\hline D-Fructose & - & $\mathrm{V}(-)$ & + & + \\
\hline$\beta$-Cyclodextrin & - & $\mathrm{V}(-)$ & + & + \\
\hline D-Mannose & - & - & + & + \\
\hline D-Malic acid & + & - & + & + \\
\hline D-Psicose & - & $\mathrm{V}(-)$ & + & + \\
\hline Pyruvic acid & - & - & + & + \\
\hline Alaninamide & - & - & + & + \\
\hline Adenosine & - & - & + & + \\
\hline Thymidine & - & - & + & + \\
\hline Dextrin & - & $\mathrm{V}(-)$ & - & + \\
\hline Mannan & - & $\mathrm{V}(-)$ & - & + \\
\hline D-Galactose & - & - & - & + \\
\hline$\alpha$-D-Glucose & - & $\mathrm{V}(-)$ & + & - \\
\hline Maltotriose & - & - & - & + \\
\hline D-Melezitose & - & - & - & + \\
\hline Palatinose & - & - & - & + \\
\hline Acetic acid & + & - & - & + \\
\hline$\alpha$-Ketoglutaric acid & + & - & + & - \\
\hline
\end{tabular}


Table 2. cont.

\begin{tabular}{|lcccc|}
\hline Test & $\begin{array}{c}\text { B. aggregatus } \\
\text { DSM }\end{array}$ & $\begin{array}{c}\text { BC425 }^{\mathrm{T}} \\
\text { related strains }\end{array}$ & BC521 & BC412 \\
\hline$\alpha$-Hydroxybutyric acid & - & - & - & + \\
Glycyl-L-glutamic acid & - & - & - & + \\
$\alpha$-Ketovaleric acid & + & $\mathrm{V}(-)$ & - & - \\
Inosine & - & - & - & - \\
Thymidine-5' & -monophosphate & - & & + \\
\hline
\end{tabular}

${ }^{*} \mathrm{C}$, Coccus, $\mathrm{R}$, rod.

$\dagger \mathrm{P}$, Pink; O, orange.

the composition of fatty acids and physiological properties. Compared with the stone surface isolates, $B$. aggregatus DSM $4725^{\mathrm{T}}$ is characterized by a rather low metabolic profile. Based on phylogenetic, genomic and phenotypic grounds, strains of the $\mathrm{BC} 444^{\mathrm{T}}$ cluster also differ from strains BC521 and BC412 and can therefore be described as representatives of a novel species of the genus Blastococcus, for which the name Blastococcus saxobsidens sp. nov. is proposed.

As a consequence of newly reported properties not included in the original description of strain DSM $4725^{\mathrm{T}}$ (Ahrens \& Moll, 1970), the description of the genus Blastococcus must be emended. At this stage, we refrain from describing strains BC521 and BC412, though, based upon genomic and phenetic evidence, these single-strain taxa would merit formal description. The rationale for not doing so is based on the finding that the novel species B. saxobsidens shows a significant number of variable and weak physiological reactions. This indicates that the intraspecies metabolic diversity is higher than is expressed by the type strain.

\section{Emended description of the genus Blastococcus Ahrens and Moll 1970}

Blastococcus (Blas.to.coc'cus. Gr. n. blastos sprout, bud; Gr. n. coccus a grain, berry; N.L. masc. n. Blastococcus the budding coccus).

A formal description has never been provided. The description is based on the morphological observations of Ahrens \& Moll (1970), supplemented with data reported in this study.

Gram-positive. Coccoid units, often reproducing by budding and multiple fission, giving rise to a variety of cell forms and aggregates. Single cells may be motile rods and vibrioid or non-motile cocci that tend to form aggregates. Formation of buds is common but not universal. One to four membranous bodies per cell may be present, which are linked to the cytoplasmic membrane. Aerobic; some cells may be microaerophilic. Strains from surfaces of marble and limestone utilize a broader spectrum of organic compounds than the only known marine strain. Predominant fatty acids are iso- $\mathrm{C}_{16: 0}$, iso- $\mathrm{C}_{16: 1}, \mathrm{C}_{18: 1} \omega 9 c$ and, in some strains, $\mathrm{C}_{17: 1} \omega 8 c$, iso- $\mathrm{C}_{15: 0}$ and $\mathrm{C}_{17: 0 \text {. Peptidoglycan }}$ contains meso- $\mathrm{A}_{2} \mathrm{pm}$ as diagnostic diamino acid. Predominant menaquinone is $\mathrm{MK}-9\left(\mathrm{H}_{4}\right)$; MK-9 may also occur in large amounts. Polar lipids consist of diphosphatidylglycerol, phosphatidylglycerol, phosphatidylinositol and phosphatidylethanolamine; two unknown phospholipids may occur. DNA G+C content is $74 \mathrm{~mol} \%$. Phylogenetically, a member of the family Geodermatophilaceae.

The type species is Blastococcus aggregatus.

\section{Emended description of Blastococcus aggregatus Ahrens and Moll 1970}

The emendation is based on the description of Ahrens \& Moll (1970), supplemented with data reported in this study.

Gram-positive, highly irregular vibrioid or rod-shaped cells occurring singly or in three-dimensional coccoid aggregates. The manifestation of one of these stages is influenced by environmental conditions. Low salt concentrations, temperatures of $5-10{ }^{\circ} \mathrm{C}$ and microaerophilic conditions favour the motile rod stage. Single cells are either motile vibrioid $(0 \cdot 3-1 \cdot 5 \times 0 \cdot 4-3 \cdot 0 \mu \mathrm{m})$ or rods or ellipsoid $(1 \cdot 2-$ $1 \cdot 5 \times 1 \cdot 5-3 \cdot 0 \mu \mathrm{m})$. Rods are often separated by disc-like septa. These motile or non-motile rods carry one to six vibrioform buds, attached to the mother cell by a tapered pole. Increased temperatures and salt concentrations induce the formation of non-motile coccoid aggregates $(1 \cdot 2-2 \cdot 5 \mu \mathrm{m}$ in diameter), appearing as linear, band-like or column-like three-dimensional forms. Larger aggregates ( $1 \mathrm{~mm}$ diameter) are separated by rectangular and/or radial partitions. Cell types of different size occur mostly side by side. After 5 days on peptone/yeast extract agar at $20^{\circ} \mathrm{C}$, colonies are pink, turbid, round and convex with a shiny surface. In liquid media, thin turbidity and formation of pink sediment is observed. Catalase-positive, oxidasenegative. No growth in mineral medium; weak growth in the presence of ethanol, but not with glucose, acetate, citrate, methanol, ethylamine or paraffin. Good growth in mineral medium plus peptone $(0.5 \%)$ and yeast extract $(0.1 \%)$; in these media, addition of $1 \%$ of either glucose, acetate, citrate, ethylamine or paraffin reduces growth. Growth is enhanced in peptone/yeast extract medium by 
the addition of $1 \% \mathrm{NaCl}$. No acid or gas from glucose, galactose, fructose, xylose, sucrose, maltose, lactose or glycerin. Methyl-red and Voges-Proskauer reactions are negative. No hydrolysis of starch, chitin, alginate or cellulose. Reactions towards substrates provided by the API ZYM, API $20 \mathrm{NE}$ and Biolog GP2 panels are indicated in Table 2. Major fatty acids are 14-methyl pentadecanoic acid (iso- $\mathrm{C}_{16: 0}$ ) and 14-methyl pentadecenoic acid (iso- $\mathrm{C}_{16: 1}$ ). Diamino acid of peptidoglycan, menaquinone and polar lipids are as described for the genus. Two unknown phospholipids may occur. Extinction maxima of carotenoids at 470 and $500 \mathrm{~nm}$. The DNA G $+\mathrm{C}$ content is $73.9 \mathrm{~mol} \%$.

The type strain, DSM $4725^{\mathrm{T}}\left(=\right.$ ATCC $25902^{\mathrm{T}}$ ), was isolated from the Baltic Sea.

\section{Description of Blastococcus saxobsidens sp. nov.}

Blastococcus saxobsidens (sax.ob'si.dens. L. n. saxum rock; L. v. obsideo to occupy; N.L. part. adj. saxobsidens rock-occupying).

Aerobic, Gram-positive. Motile and non-motile cells $(1 \cdot 0$ $1.7 \mu \mathrm{m}$ in diameter) are coccoid, occurring in tetrads with a tendency to remain aggregated. Sparse growth on LM, malt agar and YCS-Glyc agar. No growth on potato dextrose agar. Temperature range for growth is $20-37^{\circ} \mathrm{C}$, with an optimum at $32{ }^{\circ} \mathrm{C}$; growth at $\mathrm{pH} 5-8 \cdot 6$, with an optimum at $\mathrm{pH} 6 \cdot 8$. No growth at $3 \% \mathrm{NaCl}$, except strain BC448, which grows at $5 \% \mathrm{NaCl}$. Colonies are pink/orangepigmented, irregular, convex with a smooth to rough surface $(2-3 \mathrm{~mm}$ in diameter). Catalase- and oxidasepositive. Nitrate is not reduced to nitrite. Carbon sources utilized for growth are D-glucose, D-fructose, L-arabinose, ribose, myo-inositol and lactose. No acid production from D-fructose, myo-inositol or lactose. Casein, gelatin and starch are not hydrolysed. DNA, tyrosine, xanthine and hypoxanthine are not decomposed. Tweens 20, 40, 60 and 80 are not hydrolysed. Major fatty acids are 14-methyl pentadecanoic acid (iso- $\mathrm{C}_{16: 0}$ ), cis-9-heptadecenoic acid $\left(\mathrm{C}_{17: 1} \omega 8 c\right)$ and 13-methyl tetradecanoic acid (iso- $\left.\mathrm{C}_{15: 0}\right)$. Diamino acid of peptidoglycan, major menaquinone and polar lipids are as described for the genus.

The type strain, BC444 ${ }^{\mathrm{T}}\left(=\mathrm{DSM} 44509^{\mathrm{T}}=\mathrm{NRRL} 24246^{\mathrm{T}}\right)$, was isolated from limestone sampled in Malta. Other strains, BC448, BC509, BC512, BC517, BC518, BC519 and $\mathrm{BC} 525$, were isolated from calcarenite and marble from Italy and Greece. Phenotypic differences from the type strain are shown in Table 2.

\section{Acknowledgements}

This study was supported by financial contributions from CNR through finalized project 99.03872.PF36 P.R.A. and the EC (projects EVK4-1999-00061 and EVK4-2000-00028). We thank Hans Trüper for advice on the nomenclature of the novel species.

\section{References}

Ahrens, R. \& Moll, G. (1970). Ein neues knospendes Bakterium aus der Ostsee. Arch Mikrobiol 70, 243-265.

Bruce, J. (1996). Automated system rapidly identifies and characterizes microorganisms in food. Food Technol 50, 77-81.

Bunt, J. S. \& Rovira, A. D. (1955). Microbiological studies of some subantarctic soils. J Soil Sci 6, 119-128.

Collins, M. D. \& Jones, D. (1980). Lipids in the classification and identification of coryneform bacteria containing peptidoglycans based on 2,4-diaminobutyric acid. J Appl Bacteriol 48, 459-470.

Collins, M. D., Pirouz, T., Goodfellow, M. \& Minnikin, D. E. (1977). Distribution of menaquinones in actinomycetes and corynebacteria. J Gen Microbiol 100, 221-230.

DeSoete, G. (1983). A least squares algorithm for fitting additive trees to proximity data. Psychometrika 48, 621-626.

Eppard, M., Krumbein, W. E., Koch, C., Rhiel, E., Staley, J. T. \& Stackebrandt, E. (1996). Morphological, physiological, and molecular characterization of actinomycetes isolated from dry soil, rocks, and monument surfaces. Arch Microbiol 166, 12-22.

Escara, J. F. \& Hutton, J. R. (1980). Thermal stability and renaturation of DNA in dimethyl sulfoxide solutions: acceleration of the renaturation rate. Biopolymers 19, 1315-1327.

Groth, I., Schumann, P., Weiss, N., Martin, K. \& Rainey, F. A. (1996). Agrococcus jenensis gen. nov., sp. nov., a new genus of actinomycetes with diaminobutyric acid in the cell wall. Int J Syst Bacteriol 46, 234-239.

Groth, I., Schumann, P., Rainey, F. A., Martin, K., Schuetze, B. \& Augsten, K. (1997). Bogoriella caseilytica gen. nov., sp. nov., a new alkaliphilic actinomycete from a soda lake in Africa. Int $J$ Syst Bacteriol 47, 788-794.

Huß, V. A. R., Festl, H. \& Schleifer, K. H. (1983). Studies on the spectrophotometric determination of DNA hybridization from renaturation rates. Syst Appl Microbiol 4, 184-192.

Jahnke, K. D. (1992). Basic computer program for evaluation of spectroscopic DNA renaturation data from a Gilford System 2600 spectrometer on a PC/XT/AT type personal computer. J Microbiol Methods 15, 61-73.

Jukes, T. H. \& Cantor, C. R. (1969). Evolution of protein molecules. In Mammalian Protein Metabolism, pp. 21-132. Edited by H. N. Munro. New York: Academic Press.

Luedemann, G. M. (1968). Geodermatophilus, a new genus of the Dermatophilaceae (Actinomycetales). J Bacteriol 96, 1848-1858.

Luedemann, G. M. \& Fonseca, A. F. (1989). Genus Geodermatophilus Luedemann 1968, $1857^{\mathrm{AL}}$. In Bergey's Manual of Systematic Bacteriology, vol. 4, pp. 2406-2409. Edited by S. T. Williams, M. E. Sharpe \& J. G. Holt. Baltimore: Williams \& Wilkins.

Mesbah, M., Premachandran, U. \& Whitman, W. B. (1989). Precise measurement of the $\mathrm{G}+\mathrm{C}$ content of deoxyribonucleic acid by high-performance liquid chromatography. Int J Syst Bacteriol 39, 159-167.

Mevs, U., Stackebrandt, E., Schumann, P., Gallikowski, C. A. \& Hirsch, P. (2000). Modestobacter multiseptatus gen. nov., sp. nov., a budding actinomycete from soils of the Asgard Range (Transantarctic Mountains). Int J Syst Evol Microbiol 50, 337-346.

Minnikin, D. E., Collins, M. D. \& Goodfellow, M. (1979). Fatty acid and polar lipid composition in the classification of Cellulomonas, Oerskovia and related taxa. J Appl Bacteriol 47, 87-95.

Normand, P., Orso, S., Cournoyer, B., Jeannin, P., Chapelon, C., Dawson, J., Evtushenko, L. \& Misra, A. K. (1996). Molecular phylogeny of the genus Frankia and related genera and emendation of the family Frankiaceae. Int J Syst Bacteriol 46, 1-9. 
Rainey, F. A., Ward-Rainey, N., Kroppenstedt, R. M. \& Stackebrandt, E. (1996). The genus Nocardiopsis represents a phylogenetically coherent taxon and a distinct actinomycete lineage: proposal of Nocardiopsaceae fam. nov. Int J Syst Bacteriol 46, 1088-1092.

Schumann, P., Prauser, H., Rainey, F. A., Stackebrandt, E. \& Hirsch, P. (1997). Friedmanniella antarctica gen. nov., sp. nov., an LL-diaminopimelic acid-containing actinomycete from Antarctic sandstone. Int J Syst Bacteriol 47, 278-283.

Stackebrandt, E., Breymann, S., Steiner, U., Prauser, H., Weiss, N. \& Schumann, P. (2002). Re-evaluation of the status of the genus Oerskovia, reclassification of Promicromonospora enterophila (Jáger et al. 1983) as Oerskovia enterophila comb. nov. and description of Oerskovia jenensis sp. nov. and Oerskovia paurometabola sp. nov. Int $J$ Syst Evol Microbiol 52, 1105-1111.

Stead, D. E., Sellwood, J. E., Wilson, J. \& Viney, I. (1992). Evaluation of a commercial microbial identification system based on fatty acid profiles for rapid, accurate identification of plant pathogenic bacteria. J Appl Bacteriol 72, 315-321.

Urzi, C., Brusetti, L., Salamone, P., Sorlini, C., Stackebrandt, E. \& Daffonchio, D. (2001). Biodiversity of Geodermatophilaceae isolated from altered stones and monuments in the Mediterranean basin. Environ Microbiol 3, 471-479. 